v. 35, n. 3 p. $677-932$

\title{
Poda de Frutíferas
}

\author{
Eu sou a verdadeira videira e meu Pai o \\ viticultor. Toda vara em mim que não dá \\ fruto ele corta; e toda vara que dá frutos, \\ ele limpa para que dê mais abundante". \\ - João, 15:1-2.
}

A origem da poda como uma técnica cultural perde-se no tempo. Provavelmente, surgiu a partir de observações dos primeiros agricultores, que notaram que as plantas que tinham os ramos cortados, seja por mordida de animal, seja por evento natural, apresentavam um desenvolvimento singular, diferente das plantas não podadas. Nos dias atuais, a poda é uma técnica fundamental para o cultivo de algumas espécies frutíferas, como a videira e o pessegueiro, e de menor importância para outras, como os citros e o abacate.

A palavra "poda" vem do latim putare, que significa limpar, cortar, desbastar, derramar. O ato de podar, manual ou mecanicamente, consiste em operações simples que se resumem em supressões e cortes de partes das plantas, como caules, ramos, folhas, raízes, flores e frutos. Porém, no conceito fitotécnico, ou seja, na arte de cultivar plantas, principalmente as perenes, a poda é considerada uma técnica cultural utilizada para alterar o desenvolvimento natural da planta.

Didaticamente, podemos considerar como sendo três os objetivos a serem alcançados com a poda: alterar a forma, controlar a produção e manter o vigor e a sanidade da planta.

As plantas em condições naturais, sem sofrer a poda, apresentam uma copa volumosa, e seu interior é denso e sombreado. Um dos objetivos da poda é alterar a arquitetura da planta a fim de torná-la de menor porte, com mais arejamento no interior da copa. O cultivo de plantas de menor porte, além de facilitar os tratos culturais, permite aumentar a densidade de plantio e, consequentemente, obter maior produtividade. Essa poda é realizada nos primeiros anos de cultivo e pode estar associada às técnicas de inclinações de ramos e sistemas de suporte. Quando a poda atende a esse objetivo, é denominada poda de formação.

Geralmente, as plantas não podadas apresentam alternância de safras, ou seja, anos com alta produção, seguidos com anos de baixa produção. Seus frutos são menores e localizam-se na periferia da copa, muitas vezes em lugares pouco acessíveis. A poda realizada para controlar a produção tem a finalidade de equilibrar o número de frutos e o desenvolvimento vegetativo. Essa poda é denominada de produção ou frutificação.

Outros objetivos a serem alcançados são a manutenção da sanidade, o vigor e a forma da planta. São operações de retiradas de ramos infectados, débeis ou muito vigorosos e sempre com o cuidado de manter a planta no espaço a ela determinado. É realizada principalmente em plantas adultas em fase de repouso vegetativo. Essa poda pode ser denominada de manutenção, mas, nos meios agronômicos, é mais conhecida como poda de limpeza.

As podas de formação, produção e limpeza podem receber denominações diferentes de acordo com as épocas em que são realizadas (poda de inverno e verão), com o enfolhamento das plantas (poda seca e poda verde) e sua intensidade (poda drástica, renovação, esqueletamento, etc.). A denominação do tipo de poda é de menor importância, pois o que realmente interessa é o objetivo com que ela é realizada. Deve-se ressaltar que o objetivo dessas podas não é alcançado com uma ação apenas, mas, sim, numa sequência de operações (desbrota, desponte, raleio de flores e frutos, entre outros) durante o desenvolvimento da planta. 


\section{REVISTA BRASILEIRA DE FRUTICULTURA}

v. 35, n. 3 , p. $677-932$

Não se enquadram como podas fitotécnicas as que são realizadas com outros objetivos. Por exemplo, na arborização urbana, muitas vezes, são efetuadas com o objetivo de evitar que ramos entrem em contato com a rede elétrica e, embora necessárias, não devem ser consideradas como poda fitotécnica.

A técnica da poda e o conhecimento de alguns princípios básicos de fisiologia e morfologia das plantas, e sua interação com o ambiente de cultivo, associados a técnicas culturais de adubação, irrigação e uso de biorreguladores, permitem aos fruticultores controlar o desenvolvimento de diversas frutíferas, fazendo com que elas produzam em regiões e épocas não tradicionais.

Docente Sênior João Alexio Scarpare Filho Departamento de Produção Vegetal - ESALQ/USP

E-mail: jascarpa@usp.br 